\title{
What should be the protein target for adjustable Human Milk fortification in premature infants?
}

\author{
Bayram Ali Dorum ${ }^{1}$, Hilal Ozkan², \\ Salih Cagri Cakir ${ }^{3}$, Nilgun Koksal ${ }^{4}$, Gizem Ezgi Sen ${ }^{5}$
}

\begin{abstract}
Objective: To assess the short- and long-term effects of the adjustable fortification (ADJ) regimen on growth parameters in premature infants and to evaluate the amount of protein supplements given to reach the targeted blood urea nitrogen (BUN) levels.

Methods: In this retrospective study, preterm babies who were born at $\leq 32$ weeks gestational age and fed with human milk, were evaluated in two groups. Infants in Group-I were fed only standard fortification (STD). Infants in Group-II were fed the ADJ regimen. The study was conducted between 2011 and 2016.

Results: There were 123 infants in the STD group and 119 in the ADJ group. The mean gestational age of the patients in Group-I was $29.7 \pm 1.8$ weeks, and mean birth weight was $1266.1 \pm 347.1 \mathrm{~g}$. The mean gestational age of the patients in Group-II was $29.5 \pm 1.9$ weeks, and the mean birth weight was $1217.5 \pm 345.5 \mathrm{~g}$. The daily increase in weight and weekly increase in $\mathrm{HC}$ were significantly higher in the ADJ group infants. Weight and $\mathrm{HC}$ of infants in the ADJ group were significantly higher at 40 weeks. At one year corrected age, weight, length, and $\mathrm{HC}$ measurements of both groups were similar. In Group-II, 63\% of patients required additional protein supplementation up to $1.6 \mathrm{~g} /$ day to achieve the target BUN levels.

Conclusion: A higher protein intake through the ADJ regimen improves the physical growth rate of premature infants in the NICU and after discharge. However, sometimes, the targeted growth and BUN values cannot be achieved despite the administration of protein at the recommended increased doses. Increasing protein supplementation up to $1.6 \mathrm{~g} /$ day is safe, feasible, and beneficial for these infants.
\end{abstract}

KEYWORDS: Adjustable fortification, Human milk fortification, Newborn, Preterm.

How to cite this:

doi: https://doi.org/10.12669/pjms.35.1.337

Dorum BA, Ozkan H, Cakir SC, Koksal N, Sen GE. What should be the protein target for adjustable Human Milk fortification in premature infants? Pak J Med Sci. 2019;35(1):277-281. doi: https://doi.org/10.12669/pjms.35.1.337

This is an Open Access article distributed under the terms of the Creative Commons Attribution License (http://creativecommons.org/licenses/by/3.0), which permits unrestricted use, distribution, and reproduction in any medium, provided the original work is properly cited.

\section{INTRODUCTION}

Optimal growth during the care of premature infants in the Neonatal Intensive Care Unit (NICU) is similar to fetal growth. ${ }^{1,2}$ However, particularly

\footnotetext{
Correspondence:

Bayram Ali Dorum, MD. Department of Pediatrics, Uludag University Medical Faculty, Gorukle, 16059, Nilufer-Bursa, Turkey.

E-mail:bayramalidorum@gmail.com

* Received for Publication:

* $1^{\text {st }}$ Revision Received:

* $2^{\text {nd }}$ Revision Received:

* Final Revision Received:

July 6, 2018

July 12, 2018

January 8, 2019

January 10, 2019
}

in very-low-birth-weight (VLBW) infants, postnatal growth restriction continues to be a great problem. ${ }^{3}$ To prevent this, aggressive Parenteral Nutrition (PN) has become a standard practice in NICUs. ${ }^{4}$ When switching to enteral nutrition, human milk is the first and only choice for all premature and term infants. However, the feeding only with breast milk is not sufficient to meet the energy and nutritional requirements of premature infants. ${ }^{5,6}$ There is a consensus on the topic of standard fortification (STD) of human milk, particularly for VLBW infants, to ensure the provision of adequate nutrients. ${ }^{7}$

Nevertheless, it was seen that not all VLBW infants achieved the desired growth and brain development with STD. ${ }^{8}$ Thus, individualized 
fortification methods were developed. ADJ and targeted fortification methods are well-known methods of fortification for preterm neonates. ${ }^{7,9}$ These methods have improved growth in VLBW infants have therefore been successfully implemented in NICUs.

The ADJ regimen is being administered to premature infants born at $\leq 32$ weeks gestational age or weighing $\leq 1500 \mathrm{~g}$ in our unit routinely since 2014. However, in some patients, the targeted BUN levels and desirable growth were not reached by the recommended protein supplementation. For these patients, there are no clear recommendations on how to safely give high amounts of protein. In this study, we assessed short- and long-term effects of the ADJ regimen on growth parameters in premature infants born at $\leq 32$ week's gestation period. In addition, we aimed to elucidate the amount of additional protein needed to achieve the target BUN values in ADJ infants.

\section{METHODS}

This is a retrospective single-center study conducted in a tertiary NICU. In the study, premature babies fed the STD regimen or the ADJ regimen between 2011 and 2016 were examined. Infants, born $\leq 32$ weeks gestational age, who were fed fortified breast milk and whose data in the form of electronic files could be accessed were enrolled to study. Infants with major congenital anomalies, chromosomal anomalies, severe intraventricular hemorrhage, stage 2-3 necrotizing enterocolitis, severe bronchopulmonary dysplasia, and no follow-up were excluded from this study.

Infants fed only STD regimen between 2011 and 2013 were evaluated as Group-I, and those fed the ADJ regimen between 2014 and 2016 were evaluated as Group-II. The prenatal and postnatal characteristics and neonatal morbidities of both groups were recorded.

Parenteral Nutrition: According to our unit protocol, PN was started in all infants in both groups within the first few hours after birth. On the first day, $3-\mathrm{g} / \mathrm{kg} /$ day amino acid solution and $1-\mathrm{g} / \mathrm{kg} /$ day lipid infusion were started. After the first day, the amino acid solution was continued as $3.5 \mathrm{~g} / \mathrm{kg} /$ day. Every day the lipid solution was increased by $1 \mathrm{~g} / \mathrm{kg} /$ day up to $3 \mathrm{~g} / \mathrm{kg} /$ day

Enteral Nutrition: Minimal enteral feeding was initiated as soon as the infant was stable and the first milk of their mothers was obtained. Enteral feeding was increased as $20-30 \mathrm{~mL} / \mathrm{kg} /$ day. When enteral feeding reached $100 \mathrm{~mL} / \mathrm{kg} /$ day, $\mathrm{PN}$ was discontinued, and $1.1 \mathrm{~g}$ of Eoprotin ${ }^{\circledR}$ (AptamilMilupa breast milk fortifier) was added to every $25 \mathrm{~mL}$ of breast milk until the 40th week. Enteral feeding and energy amounts were increased to $140-160 \mathrm{~mL} / \mathrm{kg} /$ day and $110-130 \mathrm{kcal} / \mathrm{kg} /$ day, respectively, as long as thee infants tolerated the feeding.

BUN levels and Adjustable Fortification: In GroupII, BUN levels of infants were measured twice weekly. It was aimed to keep BUN levels between $10-16 \mathrm{mg} / \mathrm{dL}$. When the BUN levels were $<10 \mathrm{mg} /$ $\mathrm{dL}, 0.4 \mathrm{~g} /$ day protein (Protein Supplement-Milupa, $0.8 \mathrm{~g} / \mathrm{lg}$ ) was added to the infants' diet including standard fortification. In accordance with BUN levels, the supplemented protein content with 0.4 $\mathrm{g} /$ day increments was raised to a maximum of 1.6 $\mathrm{g} /$ day. After discharge, infants were evaluated weekly until the 40th week. After the 40th week, the infants were evaluated every two weeks until the $52^{\text {nd }}$ week (12 weeks corrected age). The ADJ regimen was continued until the 52nd week. Human milk protein content was assumed to be 1.5 $\mathrm{g} / 100 \mathrm{~mL}$.

Growth Characteristics: The weight, length, and head circumference of infants in both groups were documented by the same specialist nurses. Although the length and head circumference (HC) were recorded for infants on a weekly basis, weights were recorded daily. By subtracting birth

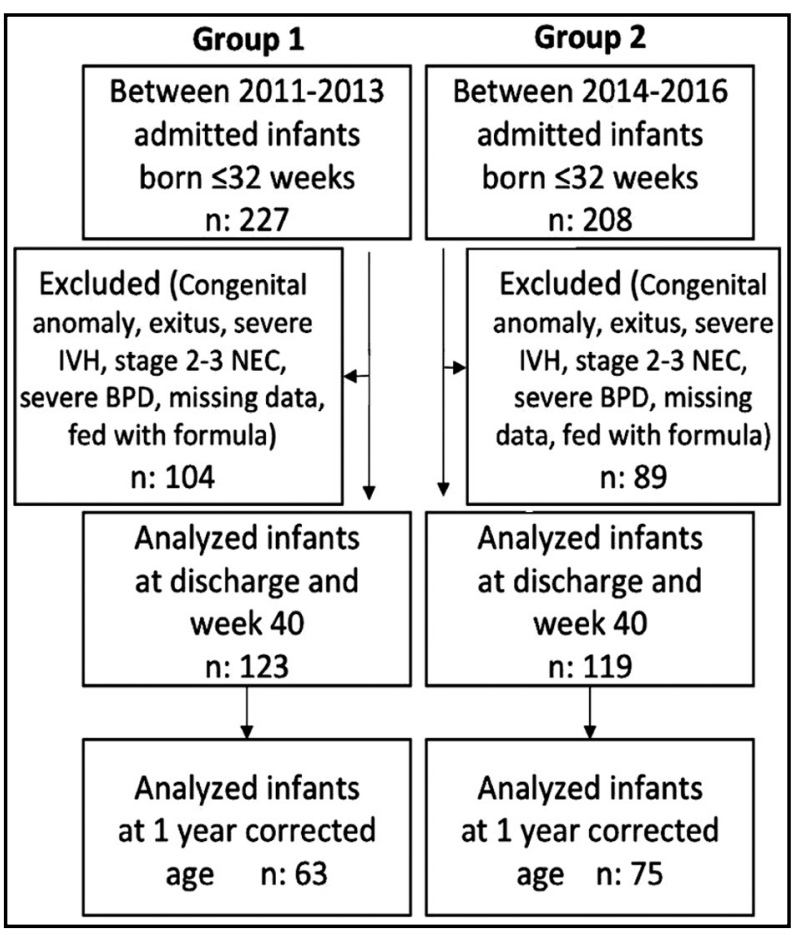

Fig.1: Flow chart of the participant infants. 
Table-I: Demographics and clinical characteristics of infants.

\begin{tabular}{lccc}
\hline & Group-I (n:123) & Group-II (n:119) & $P$ \\
\hline Preeclampsia, n (\%) & $45(36.5)$ & $41(34.4)$ & 0.83 \\
Maternal diabetes, n (\%) & $12(9.7)$ & $7(5.8)$ & 0.37 \\
Premature rupture of membranes, n (\%) & $21(17)$ & $24(20.1)$ & 0.65 \\
Male gender, n (\%) & $66(53.7)$ & $58(48.7)$ & 0.52 \\
Intrauterine growth restriction, n (\%) & $19(15.4)$ & $13(10.9)$ & 0.39 \\
Antenatal steroid, n (\%) & $68(55.2)$ & $73(61.3)$ & 0.40 \\
Cesarean section, n (\%) & $101(82.1)$ & $94(78.9)$ & 0.65 \\
Total parenteral nutrition (day) mean \pm SD & $15(4-34)$ & $14(6-39)$ & 0.06 \\
Enteral nutrition started (day), med (min-max) & $2(1-9)$ & $3(1-8)$ & 0.07 \\
Mechanical ventilation (day), med (min-max) & $1(0-46)$ & $3(0-42)$ & 0.10 \\
Sepsis, \% (n) & $40(32.5)$ & $41(34.4)$ & 0.85 \\
Respiratory distress syndrome, n (\%) & $60(48.7)$ & $57(47.8)$ & 0.99 \\
Broncho pulmonary dysplasia, $\mathrm{n}(\%)$ & $42(34.1)$ & $44(36.9)$ & 0.74 \\
Intraventricular hemorrhage, $\mathrm{n}(\%)$ & $28(22.7)$ & $28(23.5)$ & 0.88 \\
Necrotizing enter colitis, $\mathrm{n}(\%)$ & $13(10.5)$ & $12(10)$ & 0.90 \\
Hospitalization (day), med (min-max) & $40(15-99)$ & $39(19-90)$ & 0.99 \\
\hline
\end{tabular}

measurements from discharge measurements and then dividing by the duration of hospitalization, mean daily weight and weekly length and HC growth rates were calculated.

Data from both groups were compared using the Statistical Package for the Social Sciences (SPSS) 23.0 program. Normality test was done with the Shapiro-Wilk test. The t-test was used to compare the means in the two groups, and the chi-square test was used to compare the categorical data. $\mathrm{P}<0.05$ was considered significant.

\section{RESULTS}

Numbers of patients included in the study in both periods and excluded from the study are provided in the flowchart (Fig.1). The mean gestational age of the patients in Group-I was $29.7 \pm 1.8$ weeks, and mean birth weight was $1266.1 \pm 347.1 \mathrm{~g}$.

The mean gestational age of the patients in Group-II was $29.5 \pm 1.9$ weeks, and the mean birth weight was $1217.5 \pm 345.5 \mathrm{~g}$. For groups, their demographic and neonatal characteristics, APGAR scores, PN durations, neonatal morbidity rates, and hospital stays were similar (Table-I).

Although birth weight, length, and $\mathrm{HC}$ measurements were comparable for both groups, during their hospitalization, the daily weight gain and HC increase measured weekly in the ADJ group were significantly higher $(\mathrm{p}<0.05)$. Similarly, weight and $\mathrm{HC}$ of infants in the ADJ group (Group-II) were significantly higher at postnatal week 40 (Table-II). There was no significant difference in the weekly

Table-II: The comparison of the physical parameters all infants.

\begin{tabular}{lccc}
\hline & STD Group (n:123) & ADJ Group (n:119) & $P$ \\
\hline Birth HC, cm & $27.1 \pm 2$ & $26.8 \pm 2.2$ & 0.32 \\
Birth weight, $\mathrm{g}$ & $1266 \pm 347$ & $1217 \pm 345$ & 0.27 \\
Birth length, cm & $37.9 \pm 3.6$ & $37.7 \pm 3.7$ & 0.76 \\
Increase in HC at NICU, cm/ week & $0.65 \pm 0.2$ & $0.74 \pm 0.3$ & 0.01 \\
Weight gain at NICU, g/ day & $20.4 \pm 5$ & $22.6 \pm 7$ & 0.005 \\
Increase in length at NICU, cm/week & $0.72 \pm 0.2$ & $0.78 \pm 0.2$ & 0.07 \\
HC at 40th week, cm & $32.5 \pm 2.9$ & $33.4 \pm 2.8$ & 0.01 \\
Weight at 40th week, g & $2794 \pm 571$ & $2974 \pm 624$ & 0.02 \\
Length at 40th week, cm & $47.6 \pm 2.7$ & $48.1 \pm 2.3$ & 0.12 \\
\hline & $n: 63$ & $n: 75$ & \\
\hline HC at 1 year corrected age, cm & $44.8 \pm 2.1$ & $45.2 \pm 1.7$ & 0.18 \\
Weight at 1 year corrected age, $\mathrm{g}$ & $8396 \pm 1044$ & $8533 \pm 1212$ & 0.48 \\
Length at 1 year corrected age, cm & $73.1 \pm 3.1$ & $73.8 \pm 4.2$ & 0.30 \\
\hline
\end{tabular}

NICU: Neonatal Intensive Care Unit, HC: Head Circumference. 
rate of length increase during their admittance and at the 40th week. At the corrected first age, weight, length, and $\mathrm{HC}$ measurements of both groups were comparable (Table-II).

Sixty-three percent of patients fed the ADJ regimen required additional protein supplementation. Thirteen percent of these patients required protein supplementation at $0.4 \mathrm{~g} /$ day, $26 \%$ at $0.8 \mathrm{~g} /$ day, $12 \%$ at $1.2 \mathrm{~g} /$ day, and $12 \%$ at 1.6 $\mathrm{g} /$ day. With this fortification, enteral protein intake in the ADJ group was calculated as $5.1 \mathrm{~g} / \mathrm{kg} /$ day, while it was $3.9 \mathrm{~g} / \mathrm{kg} /$ day in the STD group. It was observed that $6 \%$ of the infants in the ADJ group could not reach the desired BUN levels with this protein supplementation.

\section{DISCUSSION}

In this study, the short- and long-term effects of the ADJ regimen on the growth of premature infants were examined as compared to premature infants with similar characteristics that were fed only STD. It was observed that infants fed the ADJ regimen have better growth parameters in the short term, consistent with the literature. However, it was observed that babies in both groups had similar growth measures at the one year corrected age.

In the literature, different studies have shown that the ADJ method is easy to apply, is well tolerated by premature infants, and improves their growth without increasing total energy and fluid volume. ${ }^{10,11}$ It is stated that the protein amounts recommended for these vulnerable babies could be met with this regimen. ${ }^{11}$ It has also been observed in our study that the growth of infants is better with the ADJ regimen.

The ADJ regimen was first suggested by Moro et al. and was later standardized by Arslanoglu et al., ${ }^{9,12}$ This regimen suggests a maximum $1.2 \mathrm{~g} /$ day protein supplementation for infants who could not reach the recommended BUN levels $(10-16 \mathrm{mg} / \mathrm{dL})$ despite the standard fortification. ${ }^{13}$

However, in our study, $12 \%$ of patients did not reach the target BUN values despite protein supplementation of $1.2 \mathrm{~g} /$ day. In these patients, protein supplementation amounts were increased up to $1.6 \mathrm{~g} /$ day. With this application, the daily protein intake of $3.9 \mathrm{~g} / \mathrm{kg} /$ day in the STD group was increased to $5.1 \mathrm{~g} / \mathrm{kg} /$ day in the ADJ group. Nevertheless, it has been seen that not all patients achieved the desired BUN goal or adequate growth. There is no clear recommendation in the literature about the maximum increase in enteral protein intake for such patients.
For a premature infant weighing under $1000 \mathrm{~g}$, ESPGHAN recommends a daily protein intake of $4-4.5 \mathrm{~g} / \mathrm{kg} /$ day. ${ }^{14}$ Olsen et al. reported that giving high amounts of protein (4.6-5.5 g/ kg/day) did not lead to nutritional intolerance or metabolic problems. ${ }^{15}$ Although Cochrane analysis showed that there was insufficient evidence that $>4 \mathrm{~g} /$ $\mathrm{kg} /$ day protein intake was safe, our study found that protein intake of $5.1 \mathrm{~g} / \mathrm{kg} /$ day was not associated with nutritional intolerance or metabolic disturbance. ${ }^{16}$ Similarly, it has been reported no side effects due to enteral protein uptake at $5 \mathrm{~g}$ / $\mathrm{kg} /$ day. ${ }^{17}$

In the literature, it was reported that $32 \%$ of premature infants weighing under $1250 \mathrm{~g}$ required additional protein supplementation. ${ }^{11}$ In our study, this rate was $63 \%$ in infants with similar birth weight.

It is important to monitor the premature infants that are well fed during follow-up visits. In a Cochrane analysis, there was no convincing evidence that feeding multinutrient-fortified breast milk after discharge is more advantageous for growth during infancy than feeding breast milk alone. ${ }^{18}$ However, in this study, it was found that infants fed ADJ fortification had better growth at 40th week after discharge.

In the literature, it was reported that infants who were fed individualized enteral protein supplementation had better weight gain, higher increase in head circumference, and increased mental and psychomotor developmental scores at 18 months corrected age. ${ }^{17}$ In fact, in this study, the target BUN levels were between five and nine $\mathrm{mg} / \mathrm{dL}$, and these levels were lower than the BUN levels reported by Arslanoglu et al. ${ }^{13,17}$ In our study, we did not find any significant difference between the two groups in growth parameters at one year corrected age. Unfortunately, because of the lack of data, the neurological development of the infants could not be evaluated.

Limitations of the study: It is a retrospective study and the protein content of mother's milk was not measured. Since it is chronologically later, the improved weight gain of babies in ADJ group may be influenced by the improvements of care in the NICU over the period.

In conclusion, the $\mathrm{ADJ}$ regimen improves postnatal growth of premature babies. However, the desirable growth and recommended BUN levels cannot be reached in some patients with 
the recommended daily protein supplementation quantities. In patients administered the ADJ regimen, in our study shows that increasing protein supplementation up to $1.6 \mathrm{~g} /$ day is safe, feasible, and beneficial.

\section{Grant Support \& Financial Disclosures: None.}

Conflict of Interest: The authors declared no conflict of interest.

\section{REFERENCES}

1. Wagner J, Hanson C, Anderson-Berry A. Considerations in Meeting Protein Needs of the Human Milk-Fed Preterm Infant. Adv Neonatal Care. 2014;14(4):281-289. doi: 10.1097/ ANC.0000000000000108.

2. Radmacher PG, Adamkin DH. Fortification of human milk for preterm infants. Semin Fetal Neonatal Med. 2017;22:30 35. doi: 10.1016/j.siny.2016.08.004.

3. Su BH. Optimizing nutrition in preterm infants. Pediatr Neonatol. 2014;55(1):5-13. doi:10.1016/j.pedneo.2013.07.003

4. Ziegler EE, Thureen PJ, Carlson SJ. Aggressive nutrition of the very low birth weight infant. Clin Perinatol. 2002;29(2):225-244.

5. Ziegler EE. Protein requirements of very low birth weight infants. J Pediatr Gastroenterol Nutr. 2007;45(Suppl 3):S170174. doi: 10.1097/01.mpg.0000302966.75620.91

6. Liu T-T, Dang D, Lv X-M, Wang T-F, Du J-F, Wu H. Human milk fortifier with high versus standard protein content for promoting growth of preterm infants: A meta-analysis. J Int Med Res. 2015;43(3):279-289. doi: $10.1177 / 0300060515579115$.

7. Rochow N, Fusch G, Choi A, Chessell L, Elliott L, McDonald $\mathrm{K}$, et al. Target fortification of breast milk with fat, protein, and carbohydrates for preterm infants. J Pediatr. 2013;163(4):1001-1007. doi: 10.1016/j.jpeds.2013.04.052.

8. Corvaglia L, Aceti A, Paoletti V, Mariani E, Patrono D, Ancora G, et al. Standard fortification of preterm human milk fails to meet recommended protein intake: Bedside evaluation by Near-Infrared-Reflectance-Analysis. Early Hum Dev. 2010;86(4):237-240. doi: 10.1016/j.earlhumdev.2010.04.001.

9. Arslanoglu S, Moro GE, Ziegler EE. Adjustable fortification of human milk fed to preterm infants: does it make a difference? 2006;26(10):614-621. doi: 10.1038/sj.jp.7211571

10. Alan S, Atasay B, Cakir U, Yildiz D, Kilic A, Kahvecioglu D, et al. An intention to achieve better postnatal in-hospital-growth for preterm infants: Adjustable protein fortification of human milk. Early Hum Dev. 2013;89(12):1017-1023. doi: 10.1016/j. earlhumdev.2013.08.015.

11. Picaud JC, Houeto M, Buffin R, Godbert I, Hays S. Additional protein fortification is necessary in extremely low birth weight infants fed human milk. J Pediatr Gastroenterol Nutr. 2016;63(1):103-105. doi: 10.1097/MPG.0000000000001142.
12. Moro GE, Minoli I, Jacops JR, Picone TA, Raiha NC, Ziegler EE. Fortification of human milk evaluation of a novel fortification scheme and of a new fortifier. J Pediatr Gastroenterol Nutr. 1995;20:162-172.

13. Arslanoglu S, Bertino E, Coscia A, Tonetto P, Gioliani F, Moro GE. Update of adjustable fortification regimen for preterm infants: a new protocol. J Biol Regul Homeost Agents. 2012;3:65-67.

14. Agostoni C, Buonocore G, Carnielli VP, De Curtis M, Darmaun D, Decsi T, et al. Enteral nutrient supply for preterm infants: commentary from the European Society of Paediatric Gastroenterology, Hepatology and Nutrition Committee on Nutrition. J Pediatr Gastroenterol Nutr. 2010;50(1):85-91. doi: 10.1097/MPG.0b013e3181adaee0.

15. Olsen IE, Harris CL, Lawson ML, Berseth CL. Higher protein intake improves length, not weight, $\mathrm{z}$ scores in preterm infants. J Pediatr Gastroenterol Nutr. 2014;58(4):409-416. doi: 10.1097/MPG.0000000000000237.

16. Fenton T, Premji SS, Sauve R. Higher versus lower protein intake in formula-fed low birth weight infants. Cochrane Database Syst Rev. 2014;(4):CD003959. doi: 10.1002/14651858.

17. Ergenekon E, Soysal S, Hirfanoglu I, Bas V, Gucuyener K, Turan $\mathrm{O}$, et al. Short- and long-term effects of individualized enteral protein supplementation in preterm newborns. Turk J Pediatr. 2013;55(4):365-370.

18. Young L, Embleton N, McCormick F, Mcguire W. Multinutrient fortification of human breast milk for preterm infants following hospital discharge (Review). Cochrane Database Syst Rev. 2013;(2):CD004866. doi: 10.1002/14651858.

\section{Authors Contribution:}

BAD, HO, SCC, NK, GES: Conceived, designed and did statistical analysis \& editing of manuscript. BAD, SCC, GES: Did data collection and manuscript writing.

BAD, SCC, HO, NK: Did review and final approval of manuscript.

\section{Authors:}

1. Bayram Ali Dorum, Medical Doctor Division of Neonatology,

2. Hilal Ozkan, Associate Professor, Division of Neonatology,

3. Salih Cagri Cakir, Medical Doctor, Division of Neonatology,

4. Nilgun Koksal, Professor, Division of Neonatology,

5. Gizem Ezgi Sen Medical Doctor,

1-5: Department of Pediatrics, Uludag University Medical Faculty, Nilufer-Bursa, Turkey. 